\title{
Comet assay comparison of different Corbicula fluminea (Mollusca) tissues for the detection of genotoxicity
}

\author{
Janaina Rigonato, Mário Sérgio Mantovani and Berenice Quinzani Jordão \\ Universidade Estadual de Londrina, Departamento de Biologia Geral, Londrina, PR, Brazil.
}

\begin{abstract}
The comet assay was used to study the sensitivity of the widely distributed freshwater bivalve mollusk Corbicula fluminea to the DNA-damaging alkylating-agent methylmethane sulfonate (MMS). This study was undertaken to ascertain if $C$. fluminea is a good bioindicator of pollutants in aquatic environments and identify which $C$. fluminea tissue is most effective and practical for genotoxicity studies. The mollusks were exposed to $0.6,1.2$ or $2.4 \times 10^{-4} \mathrm{M}$ MMS for 40 min and their hemolymph, gill tissue and digestive gland tissue assessed for the level of DNA damage and the time needed for the tissues to recovery. Regression analysis showed a direct linear dose-response relationship between MMS concentration and the number of damaged cells for hemolymph and digestive gland tissue but a quadratic relationship for gill tissue, which made the interpretation the gill tissue results difficult. The basal level of DNA damage to gill tissue was very high, possibly because gill is the organs most directly exposed to environmental toxins and mutagenic agents. Although all three types of tissue produced useful results, hemolymph and digestive gland tissue produced more reproducible and reliable results. Hemolymph was the best sample type in that it was easy to obtain and handle, while gill tissue required more manipulation to obtain cell suspensions. Our results indicate that $C$. fluminea is an optimal bioindicator for the determination genotoxic contaminants in aquatic environments.
\end{abstract}

Key words: Corbicula fluminea, hemolymph, gills, digestive gland, comet assay, biomonitoring.

Received: August 13, 2004; Accepted: February 15, 2005.

\section{Introduction}

Over the last few decades a number of studies have been undertaken to develop tools to determine the impact of xenobiotics on aquatic invertebrates (Le Pennec and Le Pennec, 2001). Bivalves are widely distributed sessile filter feeders which are good bioindicators of aquatic pollutants (Venier et al., 1997; López-Barea and Pueyo, 1998; Le Pennec and Le Pennec, 2001) and have often been used as test organisms in studies of aquatic pollution (Wilson et al., 1998; Mitchelmore et al., 1998; Narbonne et al., 1999; Pavlica et al., 2001; Pruski and Dixon, 2002).

The freshwater bivalve mollusk Corbicula fluminea is native to Southeast Asia but was introduced into North America at the end of the 19th century and rapidly spread throughout the Americas to become an important part of the benthic community. These mollusks have been shown to be very good bioindicators of aquatic pollution able to accumulate pollutants and show differential physiological, chemical (Johns and Luoma, 1990; Roberts, 1996; Bilos et

Send correspondence to Berenice Quinzani Jordão. Universidade Estadual de Londrina, Centro de Ciências Biológicas, Departamento de Biologia Geral, Campus Universitário, Caixa Postal 6001, 86.051-990 Londrina, PR, Brasil. E-mail: berejordao@uel.br. al., 1998; Narbonne et al., 1999) and histological (Dowling and Mothersill, 2001) responses.

The comet assay has been utilized to determine the ability of aquatic contaminants to induce DNA damage but its applicability has been the subject of intense investigation (Pavlica et al., 2001). The comet assay derives its name from the comet-like shape that cells with damaged DNA acquire due to the migration of broken DNA fragments during electrophoresis, the size of the comet tail reflecting the extent of DNA damage. The comet assay is better than other tests because it requires only a very small number of cells and these cells do not need to be undergoing active division, which means that any tissue can be evaluated. A further advantage of the comet assay is that it is a very sensitive method for determining damage in genetic material (Farbain et al., 1995; Klaude at al., 1996; Speit and Hartmann, 1999; Tice et al., 2000; Lee and Steinert, 2003).

In the study reported in this paper we used the alkaline comet test to determine whether or not the bivalve mollusk Corbicula fluminea can be used as a reliable bioindicator of DNA damage. During this study we compared the sensitivity of different $C$. fluminea tissues (hemolymph, digestive gland and gill tissues) to the 
genotoxic direct-acting alkylating agent methylmethane sulfonate (a stressor agent) and assessed the possibility of using these tissues for biomonitoring environmental genotoxic agents.

\section{Materials and Methods}

\section{Biological material}

We collected specimens of the bivalve mollusk Corbicula fluminea (2 to $3.5 \mathrm{~cm}$ long) were collected from a single site at the riverbed of the river Cambé near the town of Londrina in the Brazilian state of Paraná. The specimens were transported to the laboratory at the University of Londrina where they were detoxified by maintaining them for 30 days in a aquarium containing continuously aerated well-water.

\section{Tissue sensitivity test}

Methylmethane sulfonate (MMS, CAS: 66-27-3, Aldrich) solutions were prepared at concentrations of 0.6 , 1.2 and $2.4 \times 10^{-4} \mathrm{M}$ and five $C$. fluminea were placed in each solution for $40 \mathrm{~min}$, after which hemolymph was collected from the posterior adductor muscle of each mollusk using a syringe and transferred to $1.5 \mathrm{~mL}$ microtubes and centrifuged for $5 \mathrm{~min}$ at $268 \mathrm{~g}$. After centrifugation the supernatant was discarded and all the resultant pellet utilized for the comet assay. The gills and digestive gland of each mollusk were also removed and separately macerated in calcium- and magnesium-free phosphate-buffered saline (PBS) to obtain cell suspensions. The gill tissue required more maceration due its resistant nature. These cell suspensions were then centrifuged for $5 \mathrm{~min}$ at $268 \mathrm{~g}$. After centrifugation most of the supernatant was discarded except for about $0.5 \mathrm{~mL}$ which was used to re-suspend the pellet, $10 \mu \mathrm{L}$ of this suspension being used for the comet assay. The tissue sensitivity test was repeated four times for each mollusk by using sub-samples of the tissues collected. Mollusks exposed to water containing no MMS were used as controls and treated in the same way as those exposed to MMS.

\section{DNA damage recovery test}

The mollusks were exposed to $2.4 \times 10^{-4} \mathrm{M}$ MMS for 1 $\mathrm{h}$ and then returned to an aquarium containing continuously aerated well-water. On days $0,2,7,9$ and 30 following treatment the hemolymph of five mollusks was sampled as described above and subjected to the comet test. This test was repeated five times for each specimen by using hemolymph sub-samples from each of the mollusks. Organisms exposed to water containing no MMS were used as controls and treated in the same way as those exposed to MMS.

\section{Comet assay}

For each assay, $10 \mu \mathrm{L}$ of hemolymph pellet suspension or gill or digestive gland cell suspension were gently mixed with $120 \mu \mathrm{L}$ of $0.5 \%$ low-melting point (LMP) agarose at $37{ }^{\circ} \mathrm{C}$ and dropped on microscope slides previously covered with $1.5 \%$ normal melting point (NMP) agarose. The slides were protected with coverslips and allowed to set at $4^{\circ} \mathrm{C}$ for $15 \mathrm{~min}$. After the careful removal of the coverslip, the rest of the comet assay was conducted according to the method of Speit and Hartmann (1999), briefly summarized as follows: $1 \mathrm{~h}$ of lysis followed by $20 \mathrm{~min}$ denaturation in electrophoresis buffer $(300 \mathrm{mM}$ $\mathrm{NaOH}$ and $1 \mathrm{mM}$ EDTA - $\mathrm{pH}>13,0$, prepared from a stock solution of $10 \mathrm{~N} \mathrm{NaOH}$ and $200 \mathrm{mM}$ EDTA - pH 10.0) and then electrophoresis for $20 \mathrm{~min}$ at $25 \mathrm{~V}$ and $300 \mathrm{~mA}$ $(1.6 \mathrm{~V} / \mathrm{cm})$ followed by neutralization, fixing and staining with $0.002 \mathrm{mg} \mathrm{mL}^{-1}$ ethidium bromide. The cells were examined with a fluorescence microscope at $400 \mathrm{X}$, using a 420-490 $\mathrm{nm}$ excitation filter and a $520 \mathrm{~nm}$ emission filter. Fifty cells were scored per mollusk in the tissue sensitivity test and 100 cells in the DNA damage recovery test. These cells were classified according to the size of the comet tail: class 0 , no tail; class 1 , a small tail less than the head (nucleus) diameter; class 2 , tail length equal to or up to twice the head diameter; and class 3, tail more than twice the head diameter (Figure 1). For each treatment damage scores were calculated by summing the number of cells in each class and then multiplying this total by the class value (0-3). Samples from mollusks exposed to water containing no MMS were used as controls and the same investigator scored all the slides in blind test.

\section{Statistical analysis}

For the tissue sensitivity test data regression analysis was performed on the curves for the different MMS concentrations. The DNA damage recovery test data for mollusks treated with MMS was compared to mollusks exposed to water only using the Kruskal-Wallis test at the $5 \%$ significance level.

\section{Results}

For all the tissues studied there was a tendency towards a direct relationship between MMS concentration and the number of damaged cells or the damage score, with regression analysis showing a linearly-correlated doseresponse relationship between MMS concentration and the number of damaged cells for hemolymph and digestive gland tissue but a quadratic relationship for gill tissue (Figure 2). For all three tissues class 1 damage was the most frequent type and class 3 the least frequent (Figure 2).

Hemolymph (Figure 3a) and digestive gland tissue (Figure 3b) which had not been exposed to MMS showed low background damage which made it easy to evaluate the response of the cells to MMS. There was a high number of class 1 and 2 cells in control gill tissue which had not been exposed to MMS (Figure 3c), such results indicating a high level of baseline damage in this tissue. 

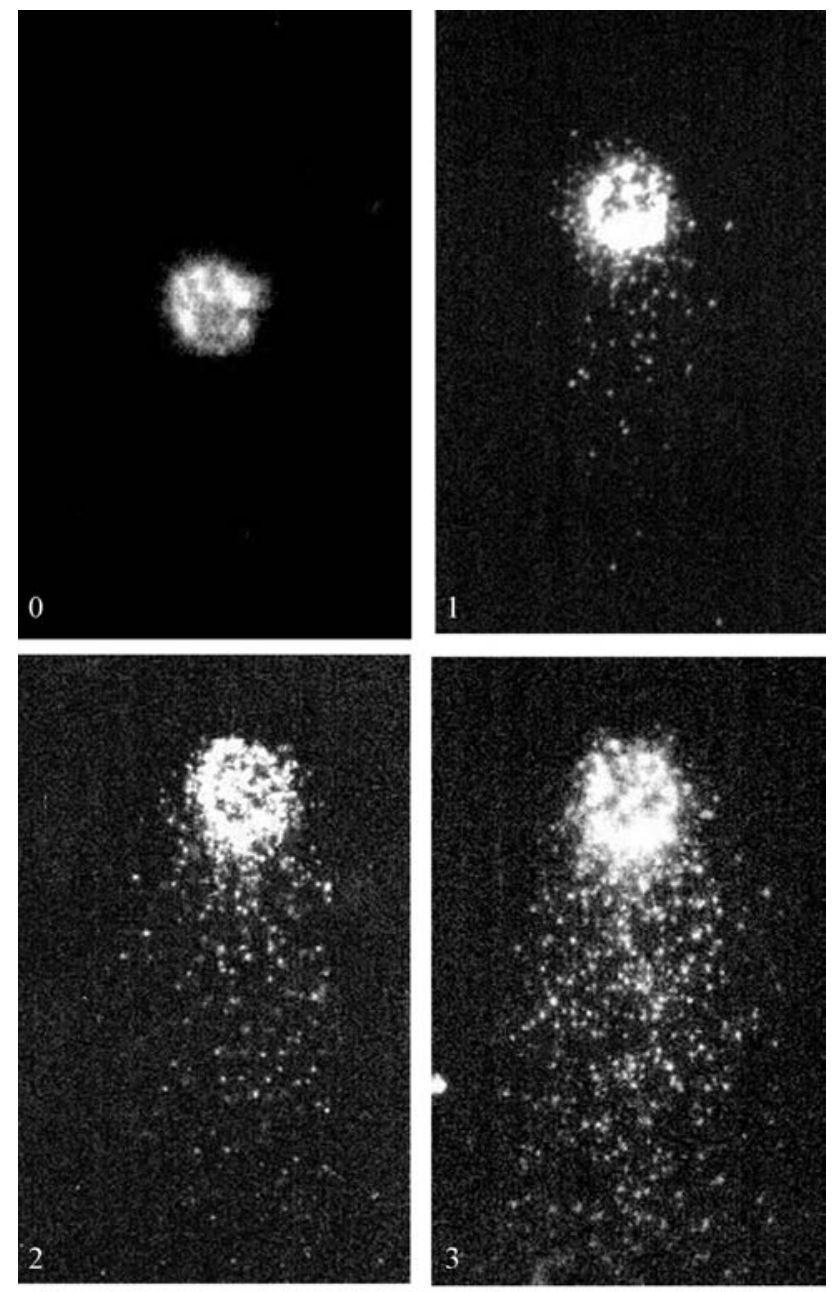

Figure 1 - Hemolymph cells exposed to methylmethane sulfonate (MMS). Class 0: undamaged cells; classes 1,2 and 3: from the less to more damaged cells.

When hemolymph cells were allowed to recover for two days there was a gradual reduction in genotoxic damage as measured by the number of damaged cells and the damage score, this reduction peaking on the ninth day of recovery and remaining constant until day 30 (Figure 4). In the comet assay the basal level of DNA damage in hemolymph cells appears to be about 9.6\%. Figure 4 also indicates that for recovering cells there was a time-related shift in the type and frequency of damaged cells from the more damaged class 3 and 2 cells to less damaged class 1 or undamaged class 0 cells.

\section{Discussion}

In this work was found that C. fluminea is a good bioindicator of genotoxic agents, with the tissues studied showing a good correlation and a very clear dose-response effect between increased MMS concentration and increased DNA lesions. The gills appear to be the least appropriate organ to study because cells from this organ show

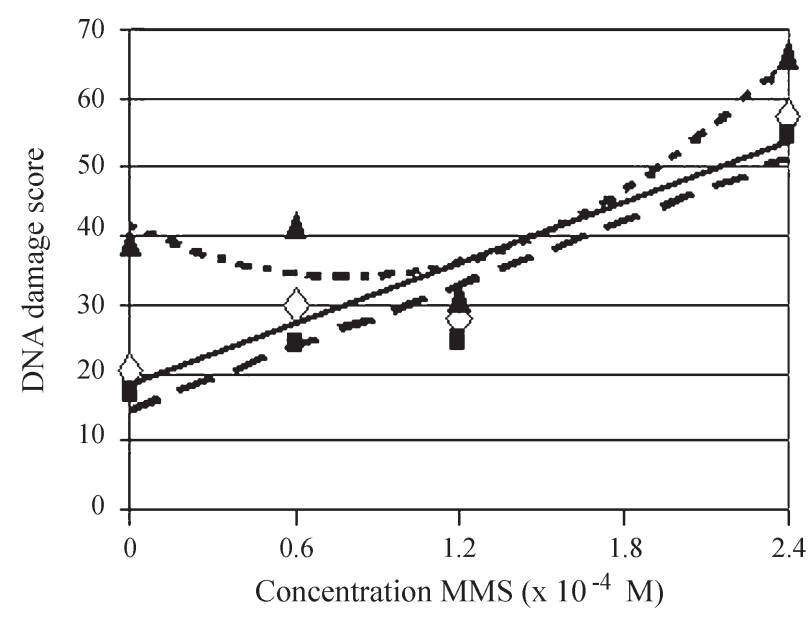

Figure 2 - Cell damage scores for hemolymph, digestive gland tissue and gill tissue after treatment with methylmethane sulfonate (MMS). Key:

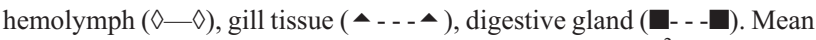
values for 4 replicates. Hemolymph $\mathrm{y}=14.821 \mathrm{x}+18.25 / \mathrm{R}^{2}=0.882$. Digestive gland tissue $\mathrm{y}=15.508 \mathrm{x}+14.05 / \mathrm{R}^{2}=0.8959$. Gill tissue $\mathrm{y}=12.216 \mathrm{x}^{2}-19.33 \mathrm{x}+41.645 / \mathrm{R}^{2}=0.8799$.

elevated baseline levels of DNA damage which could mask the results and the quadratic relationship between cell damage and mutagenic agent dose makes interpretation of results difficult. Hemolymph and digestive gland tissue were good indicators of genotoxicity because both showed low baseline damage and a direct linear response to mutagen (stressor agent) concentration, both of which simplify the interpretation of results when assessing the effects of harmful agents present in the environment.

The fact that gill cells showed a very high basal level of DNA damage may have been because it was very difficulty to obtain a cell suspension from the gill and the large amount of manipulation required to obtain cell suspensions of this organ may have led to mechanical injury to the cells and increased DNA damage.

Because they are constantly exposed to oxygen radicals and other oxidants (oxidative stress) aerobic organisms are subject to high levels of damage in all cellular components, DNA included, and this can be the cause of the high baseline comet damage found in Mytilus edulis (Wilson et al., 1998).

Rank and Jensen (2003) performed comet assays on M. edulis hemolymph and gill cells exposed to MMS and found that, although both tissues were equally sensitive to MMS, hemolymph was better for in vivo studies because it was much simpler to collect and handle. When working with live organisms it should be born in mind that there is natural inter-individual genetic variation (Nacci et al., 1996; Mitchelmore and Chipman, 1998) and suitable controls are essential to guarantee successful studies. The fact that $C$. fluminea can exhibit hermaphrodism, selffertilization and hence decreased inter-individual variation favors the use of this mollusk in biomonitoring studies. 

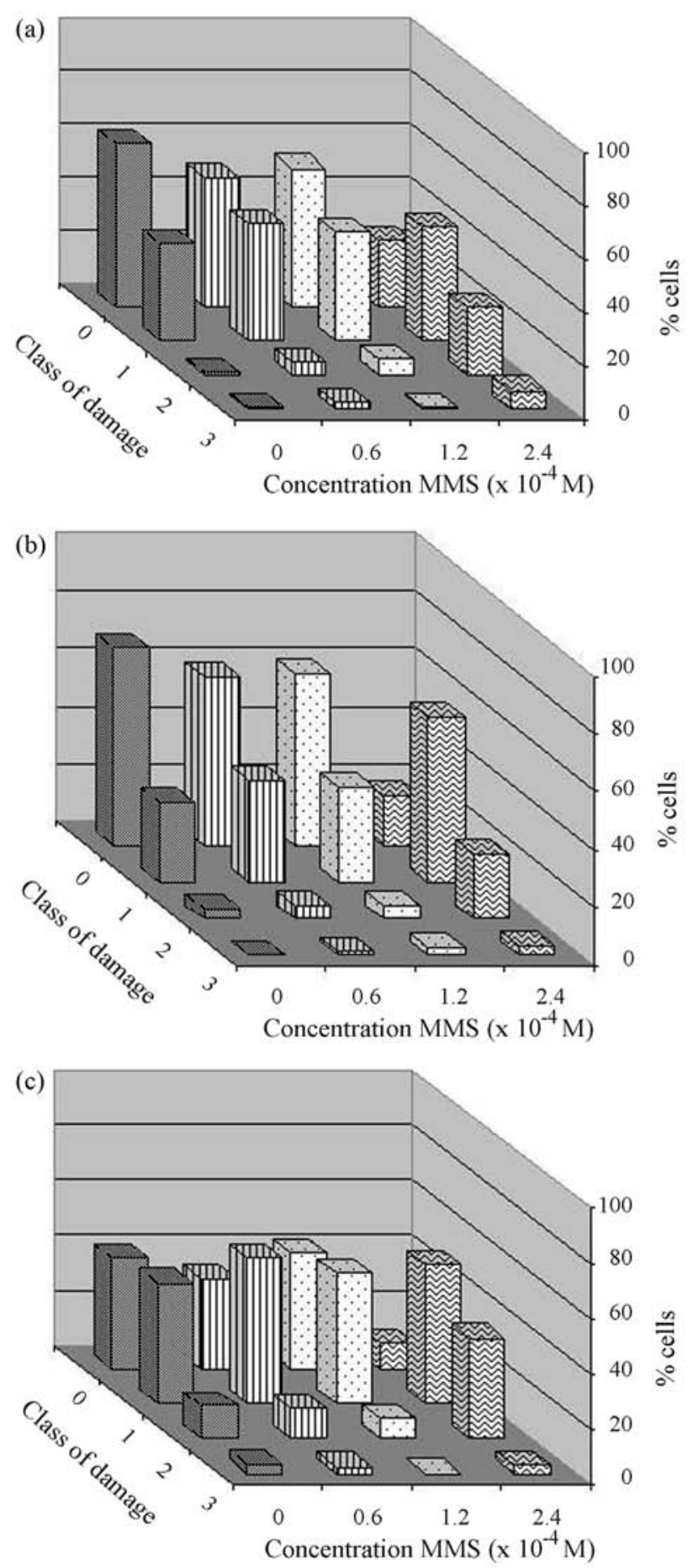

Figure 3 - Frequency of DNA damage in hemolymph (a), digestive gland (b) and gill (c) cells after treatment with methylmethane sulfonate (MMS). Mean values for 4 replicates.

In this study the $C$. fluminea cell types studied showed rapid reversal of the MMS-induced genotoxic damage with a reduction in the number of damaged cells occurring nine days after MMS exposure, this reversal possibly being due to apoptosis or repair systems in the damaged cells. If apoptosis was responsible for the elimination of cells $C$. fluminea

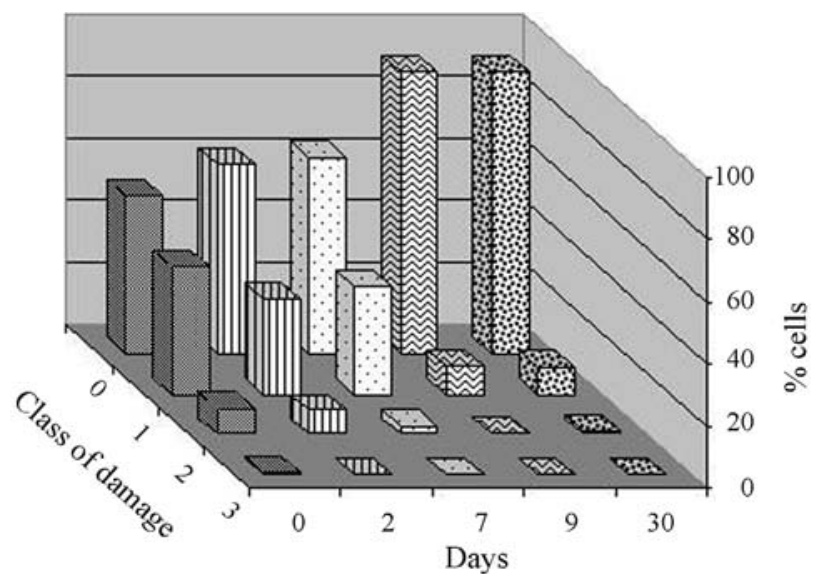

Figure 4 - Frequency of DNA damage in hemolymph cells at different recovery times after treatment with methylmethane sulfonate (MMS). For each point 500 cells from five replicates were examined.

would have a highly active cell replacement system to avoid injury to vital functions, but in our study the mortality index was low and no apoptotic cells were detected. The ability of $C$. fluminea to recover from damage when unexposed to mutagens support the notion that there should be a 30-day detoxification period in the laboratory before exposing this mollusk to genotoxic agents.

Mitchelmore et al. (1998) reported that 20\% of $M$. edulis digestive gland cells can be expected to exhibit low-level DNA damage (measurable by the comet assay) caused by cell-breakage during isolation and that digestive gland cells taken from $M$. edulis show many DNA breaks compared to other vertebrate cell types. Our study with $C$. fluminea showed that maximum recovery from DNA damage $(9.6 \%)$ occurred and leveled off after nine days, indicating that $C$. fluminea could be recommended for the monitoring of aquatic environments in response to some type of ecological disaster and that this mollusk is capable of determining when the environment has returned to acceptable conditions.

The present study suggests that Corbicula fluminea is an optimal biomonitor of aquatic environments and it contains various tissues and organs capable of furnishing good responses to genotoxicity. Other studies (Venier et al., 1997; Klobuèar et al., 2003; Rank and Jensen, 2003) have shown that hemolymph is a good tissue for the in vivo evaluation of organisms exposed to environmental pollutantsfi. Also these findings suggests that $C$. fluminea hemolymph is a valuable target tissue because of its ease of manipulation and its efficient response to DNA-stressing compounds. It therefore seems that $C$. fluminea could be useful in establishing tests to determine genotoxicity in aquatic environments.

\section{Acknowledgments}

This study was supported by the Brazilian agency CAPES/MEC. 


\section{References}

Bilos C, Colombo JC, Presa MJR (1998) Trace metals in suspended particles, sediments and Asiatic clams (Corbicula fluminea) of the Río de la Plata Estuary, Argentina. Environ Pollution 99:1-11.

Dowling K and Mothersill C (2001) The further development of rainbow trout primary epithelial cell cultures as a diagnostic tool in ecogenotoxicology risk assessment. Aquatic Toxicol 53:279-289.

Farbain DW, Olive PL and O'Neil KL (1995) The comet assay: A comprehensive review. Mutat Res 339:37-59.

Johns C and Luoma SN (1990) Arsenic in benthic bivalves of San Francisco Bay and the Sacramento/San Joaquin River delta, The Science of the Total Environ 97/98:673-684.

Klaude M, Eriksson S, Nygren J and Ahnström G (1996) The comet assay: Mechanisms and technical considerations. Mutat Res 363:89-96.

Klobuèar GIV, Pavlica M, Erben R and Pape D (2003) Application of the micronucleus and comet assays to mussel Dreissena polymorpha haemocytes for genotoxicity monitoring of freshwater environments. Aquatic Toxicol 64:15-23.

Le Pennec G and Le Pennec M (2001) Evaluation of the toxicity of chemical compounds using digestive acini of the bivalve mollusk Pecten maximus $\mathrm{L}$. maintained alive in vitro. Aquat Toxicol 53:1-7.

Lee RF and Steinert S (2003) Use of the single cell gel electrophoresis/comet assay for detecting DNA damage in aquatic (marine and freshwater) animals. Mutat Res 544:43-64.

López-Barea J and Pueyo C (1998) Mutagen content and metabolic activation of promutagens by molluscs as biomarkers of marine pollution. Mutat Res 399:3-15.

Mitchelmore CL and Chipman JK (1998) DNA strand breakage in aquatic organisms and the potential values of the comet assay in environmental monitoring. Mutat Res 399:135-147.

Mitchelmore CL, Birmelin C, Livingstone DR and Chipman JK (1998) Detection of DNA strand breaks in isolated mussel
(Mytilus edulis L.) digestive gland cells using the "comet" assay. Ecotoxicol Environ Saf 41:51-58.

Nacci DF, Cayula S and Jackim F (1996) Detection of DNA damage in individual cells from marine organisms using the single cell gel assay. Aquatic Toxicol 35:197-210.

Narbonne JF, Djomo JE, Ribeira, FV and Garrigues P (1999) Accumulation kinetics of polycyclic aromatic hydrocarbons adsorbed to sediment by the mollusk Corbicula fluminea Ecotoxicol Environ Saf 42:1-8.

Pavlica M, Klobuèar GIV, Moja N, Erben R and Pape D (2001) Detection of DNA damage in haemocytes of zebra mussel using comet assay. Mutat Res 490:209-214.

Pruski AM and Dixon DR (2002) Effects of cadmium on nuclear integrity and DNA repair efficiency in the gill cells of Mytilus edulis L. Aquatic Toxicol 57:127-137.

Rank J and Jensen K (2003) Comet assay on gill cells and hemocytes from the blue mussel Mitylus edulis. Ecotoxicol Environ Saf 54:323-329.

Roberts CA (1996) Selenium contamination in Corbicula transplanted into agricultural drains in the Imperial Valley, California, Division of Environ. Contaminants, Carsbad Field Office U.S. Fish and Wildlife Service, August.

Speit G and Hartmann A (1999) The comet assay (single-cell gel test). In Henderson DS (ed) Methods in Molecular Biology, v.113, DNA Repair Protocols: Eukaryotic Systems. Humana Press, Totowa, pp 203-212.

Tice RR, Agurell E, Anderson D, Burlinson B, Hartmann A, Kobayashi H, Miyamae Y, Rojas E, Ryu JC and Sasaki YF (2000) Single cell gel/comet assay: Guidelines for in vitro and in vivo genetic toxicology testing. Environ Molec Mutagenesis 35:206-221.

Venier P, Maron S and Canova S (1997) Detection of micronuclei in gill cells and haemocytes of mussels exposed to benzo[a]pyrene. Mutat Res 390:33-44.

Wilson JT, Pascoe PL, Parry JM and Dixon DR (1998) Evaluation of comet assay as a method for the detection of DNA damage in cells of a marine invertebrate, Mytilus edulis L. (Mollusca, Pelecipoda). Mutat Res 399:87-95.

Associate Editor: Carlos F.M. Menck 